\title{
PENERAPATAN MODEL-MODEL PEMBELAJARAN MELALUI KEGIATAN SUPERVISI KELAS UNTUK MENINGKATKAN KEMAMPUAN GURU DI SMA NEGERI 1 SIBOLGA, KOTA SIBOLGA
}

\author{
Ali Sutan Lubis \\ Sekolah Menengah Atas Negeri 1 Sibolga, Sumatera Utara, \\ sutanlubis11@yahoo.co.id
}

\begin{abstract}
Abstrak: Tujuan dalam penelitian ini adalah: (1) meningkatkan mutu pembelajaran siswa dengan enerapan model-model pembelajaran melalui kegiatan supervisi akademik dengan pendekatan realistik; (2) mengetahui kendala-kendala yang dihadapi guru dalam penerapan model-model pembelajaran melalui kegiatan supervisi akademik dengan pendekatan realistik; (3) meningkatkan kemampuan siswa terhadap penerapan model-model pembelajaran melalui kegiatan supervisi akademik dengan pendekatan realistik pada pembelajaran di kelas si SMA N 1 Sibolga. Hasil penelitian menunjukkan bahwa; (1) bimbingan dan pengawasan yang berkesinambungan dapat meningkatkan motivasi guru dalam menyusun RPP dengan lengkap; (2) bimbingan berkesinambungan dapat meningkatkan kompetensi guru dalam menyusun RPP. Peningkatan kompetensi guru dalam menyusun RPP dari siklus ke siklus. Pada siklus pertama nilai ratarata komponen RPP 60,5\% dan pada siklus kedua 87,9\%. Jadi, terjadi peningkatan 27,4\% dari siklus pertama; dan (3) supervisi akademik membuka cakrawala berpikir guru, untuk memandang dirinya, menemukan kesalahan dan solusi atas kompetensi diri guru itu sendiri.
\end{abstract}

Kata Kunci: kemampuan guru, menerapkan model-model pembelajaran, supervisi

Abstract: The aim of this research are: (1) improve the quality of learning of students with Application of models of learning through academic supervision by a realistic approach; (2) determine the constraints faced by teachers in the application of learning models through academic supervision by a realistic approach; (3) improve the ability of students to the application of learning models through academic supervision by a realistic approach to learning in class SMA N 1 Sibolga. The results showed that; (1) continuous guidance and supervision to increase the motivation of teachers in developing lesson plans to complete; (2) continuous guidance can improve the competence of teachers in preparing lesson plans. Increased competence of teachers in preparing lesson plans from cycle to cycle. In the first cycle of the average value of the RPP component of 60.5\% and $87.9 \%$ in the second cycle. Thus, an increase of $27.4 \%$ from the first cycle; and (3) the academic supervision open up the minds of teachers, to look at him, finding errors and solutions to the competence of the teacher's own self.

Keywords: the ability of teachers, applying learning models, supervision

\section{PENDAHULUAN}

Sekolah sebagai lembaga pendidikan dan suatu organisasi haruslah selalu mengikuti perkembangan dunia ilmu pengetahuan, teknologi dan budaya, sertan tuntutan masyarakat sebagai pengguna jasa dan layanan. Untuk memperoleh hasil tersebut agar sesuai dengan harapan, maka diperlukan sekolah yang mempunyai sumberdaya yang handal.Sekolah sebagai lembaga pendidikan formal terdiri dari beberapa komponen yang saling berkaitan, yaitu kepala sekolah, guru, pegawai, konselor, siswa, serta komite sekolah yang digolongkan sebagai sumber daya manusia yang saling bekerjasama untuk mencapai tujuan organisasi yang telah ditentukan.

Sebagai lembaga formal Sekolah berfungsi membantu khususnya orang tua dalam memberikan pendidikan kepada anak- anak mereka. Sekolah memberikan pengetahuan, keterampilan dan sikap kepada anak didiknya secara lengkap sesuai dengan yang mereka butuhkan. Sekolah sebagai lembaga pendidikan dan suatu organisasi haruslah selalu mengikuti perkembangan dunia ilmu pengetahuan, teknologi dan budaya, serta tuntutan masyarakat sebagai pengguna jasa dan layanan. Untuk memperoleh hasil tersebut agar sesuai dengan harapan, maka diperlukan sekolah yang mempunyai sumberdaya yang handal. Menurut Fattah (2003:1) bahwa Sekolah merupakan wadah tempat proses pendidikan, memiliki sistem yang kompleks dan dinamis. Ini menunjukkan bahwa Sekolah merupakan suatu organisasi yang berperan dalam penyelenggaraan pendidikan. Sekolah sebagai lembaga pendidikan formal terdiri dari beberapa komponen yang saling berkaitan, 
yaitu kepala sekolah, guru, pegawai, konselor, siswa, serta komite sekolah yang digolongkan sebagai sumber daya manusia yang saling bekerjasama untuk mencapai tujuan organisasi yang telah ditentukan.

Semua fungsi sekolah tersebut tidak akan efektif apabila komponen dari sistem sekolah tidak berjalan dengan baik, karena kelemahan dari salah satu komponen akan berpengaruh pada komponen yang lain yang pada akhirnya akan berpengaruh juga pada jalannya sistem itu sendiri. Salah satu dari bagian komponen sekolah adalah guru.

Guru sebagai suatu asset sumber daya manusia merupakan salah satu komponen penting dalam proses pembelajaran di Sekolah. Guru memiliki peran sebagai pengajar, pendidik, dan pelatih bagi siswa, dan merupakan agen perubahan sosial (agent of social change) yang dapat mengubah pola pikir, sikap, dan perilaku siswa menuju kehidupan yang lebih baik, dan mandiri. Tugas dan kewajiban serta tanggung jawab guru sebagai pengajar dan pendidik, ternyata merupakan pekerjaan yang tidak mudah. Untuk dapat melaksanakan tugas dan tanggung jawab di atas, seorang guru yang professional dituntut memiliki beberapa kemampuan dan keterampilan tertentu. Hal ini disebabkan peranan guru dalam proses pembelajaran meliputi banyak hal, di antaranya sebagai pengajar, pemimpin kelas, pembimbing, perencana, supervisor, motivator, dan konselor. Sebagai tulang punggung pendidikan, guru diharapkan mampu melaksanakan tugas-tugas dan fungsinya demi tercapainya tujuan pendidikan. Guru yang baik dalam melaksanakan tugas dan fungsinya akan berupaya mengembangkan potensi-potensi yang ada pada peserta didik, sebagaimana yang diamanatkan Undang-Undang Sistem Pendidikan Nasional Nomor 20 Tahun 2003.

Guru dituntut untuk mampu menguasai kurikulum, menguasai materi, menguasai metode, dan tidak kalah pentingnya guru juga harus mampu mengelola kelas sedemikian rupa sehingga pembelajaran berlangsung secara aktif, inovatif dan menyenangkan. Namun umumnya guru masih mendominasi kelas, siswa pasif Guru memberikan konsep, sementara siswa menerima bahan jadi. menurut Erman Suherman, ada hal yang menyebabkan siswa tidak menikmati (senang) untuk belajar, yaitu kebanyakan siswa tidak siap terlebih dahulu dengan (minimal) membaca bahan yang akan dipelajari, siswa datang tanpa bekal pengetahuan seperti membawa wadah kosong. Lebih parah lagi, siswa tidak menyadari tujuan belajar yang sebenarnya, tidak mengetahui manfaat belajar bagi masa depannya nanti.

Berdasarkan pengamatan penulis di SMA N 1 Sibolga, terdapat beberapa kendala pada pembelajaran selama ini antara lain :

1. Siswa mengalami kesulitan dalam memahami konsep.

2. Siswa kurang aktif/siswa pasif dalam proses pembelajaran.

3. Siswa belum terbiasa untuk bekerja sama dengan temannya dalam belajar.

4. Guru kurang mengaitkan materi pembelajaran dengan kehidupan sehari-hari.

5. Hasil nilai ulangan / hasil belajar siswa pada pembelajaran rendah.

6. KKM tidak tercapai.

7. Pembelajaran tidak menyenangkan bagi siswa.

8. Kurangnya minat siswa terhadap pembelajaran.

Sebagai pendidik, penulis melihat pembelajaran menjadi kurang efektif karena hanya cenderung mengedepankan aspek intelektual dan mengesampingkan aspek pembentukan karakter. Hal ini tentu suatu hambatan bagi guru. Namun penulis ingin mengubah hambatan tersebut menjadi sebuah kekuatan dalam pengelolaan kegiatan belajar mengajar yang efektif dan efisien sehingga nantinya akan mendapatkan hasil yang memuaskan.

Untuk menjawab hal itu, penulis mencoba memberi solusi kepada guru-guru untuk menerapkan model-model pembelajaran melalui kegiatan supervisi Akademik dengan pendekatan Realistik di SMA N 1 Sibolga, dengan menyusun berbagai perangkat pembelajaran yang dibutuhkan seperti: RPP, alat peraga, teknik pengumpulan data, dan instrumen yang dibutuhkan untuk membantu guru dalam mengelola kelas dan mengevaluasi pembelajaran yang dilakukan.

Guru merupakan sosok yang digugu dan ditiru, begitu ungkapan yang sering kita dengar. Guru menjadi pendidik juga pengajar. "Guru profesional harus memiliki empat kompetensi, yaitu pedagogis, kepribadian, sosial dan profesinal. Kompetensi pedagogis adalah kemampuan seorang pendidik mengelola pembelaajaran peserta didik. Kompetensi kepribadian adalah kemampuan kepribadian yang mantap, berakhlak mulia, arif, dan berwibawa serta menjadi teladan peserta didik. 
Kompetensi sosial adalah kemampuan berkomunikasi dan berinteraksi secara efektif dan efesien dengan peserta didik, sesama pendidik, teman sejawat, dan masyarakat sekitar. Kompetensi profesional adalah kemampuan penguasan materi pelajaran secara luas dan mendalam." (Sagala, 2011,31)

Semua kompetensi tersebut mengajak guru untuk mampu menjadi sosok yang digugu dan ditiru, baik sebagai pengajar, pendidik, fasilitator, evaluator, motivator dan masih banyak lagi. Kompetensi itu juga membawa guru sebagai seorang pembelajar, dalam melaksanakan pembelajaran tentu guru menerapkan model pembelajaran yang sesuai dengan karakteristik materi dan peserta ajar.

Model pembelajaran itu sendiri dapat diartikan sebagai kerangka konseptual yang melukiskan prosedur yang sistematik dalam mengorganisasikan pengalaman belajar untuk mencapai tujuan belajar tertentu dan berfungsi sebagai pedoman bagi perancang pengajaran dan para guru dalam merencanakan dan melaksanakan aktifitas belajar mengajar (Udin Winataputra, 1994,34).

Banyak model-model pembelajaran yang dapat dikembangkan oleh guru dalam proses kegiatan belajar mengajar yang pada prinsipnya pengembangan model pembelajaran bertujuan untuk menciptakan situasi belajar mengajar yang efetif dan efisien, menyenangkan, bermakna, lebih banyak mengaktifkan siswa.

Dalam pengembangan model pembelajaran yang mendapat penekanan pengembangannya terutama dalam strategi dan metode pembelajaran. Untuk masa sekarang ini perlu juga dikembangkan system penilaian yang mencakup ranah kognitif, afektif dan psikomotorik. Oleh karena itu guru dalam pelaksanaan proses belajar mengajar bisa saja mengembangkan model pembelajaran sendiri dengan tujuan proses pembelajaran lebih efektif dan efisien, lebih banyak memberikan kesempatan kepada siswa untuk berkreasi, sehingga siswa lebih aktif.

Berikut ini adalah pengertian model pembelajaran menurut pendapat para tokoh pendidikan antara lain:

1. Agus Suprijono: pola yang digunakan sebagai pedoman dalam merencanakan pembelajaran di kelas maupun tutorial.

2. Mills: "model adalah bentuk representasi akurat sebagai proses actual yang memungkinkan seseorang atau sekelompok orang mencoba bertindak berdasarkan model itu"

3. Richard I Arends: model pembelajaran mengacu pada pendekatan yang akan digunakan, termasuk di dalamnya tujuantujuan pembelajaran, tahap-tahap kegiatan di dalam pembelajaran, lingkungan pembelajaran dan pengelolaan kelas.

Kompetensi dasar adalah sejumlah kemampuan yang harus dikuasai peserta didik dalam mata pelajaran tertentu sebagai rujukan penyusunan indikator kompetensi dalam suatu pelajaran.

\section{Supervisi Akademik}

Salah satu program yang dapat diselenggarakan dalam rangka pemberdayaan guru adalah supervisi akademik (supervisi akademik).Supervisi akademik adalah serangkaian kegiatan membantu guru mengembangkan kemampuannya mengelola proses pembelajaran demi pencapaian tujuan akademik. Supervisi akademik merupakan upaya membantu guru-guru mengembangkan kemampuannya mencapai tujuan akademik. Dengan demikian, berarti, esensial supervisi akademik adalah membantu guru mengembangkan kemampuan profesionalismenya. Mengembangkan kemampuan dalam konteks ini janganlah ditafsirkan secara sempit, semata-mata ditekankan pada peningkatan pengetahuan dan keterampilan mengajar guru, melainkan juga pada peningkatan komitmen (commitmen) atau kemauan (willingness) atau motivasi (motivation) guru, sebab dengan meningkatkan kemampuan dan motivasi kerja guru, kualitas akademik akan meningkat

Tujuan supervisi akademik adalah:

a. Membantu guru mengembangkan kompetensinya,

b. Mengembangkan kurikulum,

c. Mengembangkan kelompok kerja guru, dan membimbing penelitian tindakan kelas (PTK) (Glickman, et al; 2007, Sergiovanni, 1987).

Supervisi akademik merupakan salah satu (fungsi mendasar (essential function) dalam keseluruhan program sekolah (Weingartner, 1973; Alfonso dkk., 1981; dan Glickman, et al; 2007). Hasil supervisi akademik berfungsi sebagai sumber informasi bagi pengembangan profesionalisme guru.

Supervisi akademik adalah serangkaian kegiatan membantu guru mengembangkan 
kemampuan mengelola proses pembelajaran untuk mencapai tujuan pembelajaran (Daresh, 1989, Glicman, et al; 2007). Supervisi akademik tidak terlepas dari penilaian kinerja guru dalam mengelola pembelajaran.

Prinsip-prinsip supervisi akademik:

a. Praktis, artinya mudah dikerjakan sesuai kondisi sekolah.

b. Sistematis artinya dikembangkan sesuai perencanaan program supervise yang matang dan tujuan pembelajaran

c. Objektif artinya masukan sesuai aspek-aspek instrument

d. Realistis artinya berdasarkan kenyataan sebenarnya

e. Antisipatif artinya mampu menghadapi masalah-masalah yang mungkin akan terjadi

f. Konstruktif artinya mengembangkan kreativitas dan inovasi guru dalam mengembangkan proses pembelajaran.

g. Kooperatif artinya ada kerjasama yang baik antara supervisor dan guru dalam mengembangkan pembelajaran.

h. Kekeluargaan artinya mempertimbangkan saling asah, asih, dan asuh dalam mengembangkan pembelajaran.

i. Demokratis artinya supervisor tidak boleh mendominasi pelaksanaan supervise akademik.

j. Aktif artinya guru dan supervisor harus aktif berpartisipasi

k. Humanis artinya mampu menciptakan hubungan kemanusian yang harmonis, terbuka, jujur, sabar, antusias dan penuh humor.

1. Berkesinambungan artinya supervise akademik dilakukan secara teratur dan berkelanjutan oleh kepala sekolah.

m. Terpadu, artinya menyatu dengan program pendidikan

n. Komprehensif artinya memenuhi ketiga tujuan supervise akademik diatas.

\section{Pendekatan Realistik}

Pembelajaran selama ini terlalu dipengaruhi pandangan bahwa Pembelajaran merupakan alat yang siap pakai. Pandangan ini mendorong guru bersikap cenderung memberi tahu konsep/ sifat/ teorema dan cara menggunakannya. Guru cenderung mentransfer pengetahuan yang dimiliki ke pikiran anak dan anak menerimanya secara pasif dan tidak kritis. Adakalanya siswa menjawab soal dengan benar namun mereka tidak dapat mengungkapkan alasan atas jawaban mereka. Siswa dapat menggunakan rumus tetapi tidak tahu dari mana asalnya rumus itu dan mengapa rumus itu digunakan. Keadaan demikian mungkin terjadi karena di dalam proses pembelajaran tersebut siswa kurang diberi kesempatan dalam mengungkapkan ide-ide dan alasan jawaban mereka sehingga kurang terbiasa untuk mengungkapkan ide-ide atau alasan dari jawabannya.

Perubahan cara berpikir yang perlu sejak awal diperhatikan ialah bahwa hasil belajar siswa meruapakan tanggung jawab siswa sendiri. Artinya bahwa hasil belajar siswa dipengaruhi secara langsung oleh karakteristik siswa sendiri dan pengalaman belajarnya. Tanggung jawab langsung guru sebenarnya pada penciptaan kondisi belajar yang memungkinkan siswa memperoleh pengalaman belajar yang baik (Marpaung, 2004). Pengalaman belajar akan terbentuk apabila siswa ikut terlibat dalam pembelajaran yang terlihat dari aktivitas belajarnya.

Pendekatan realistic menekankan untuk membawa pembelajaran pada pengajaran bermakna dengan mengkaitkannya dalam kehidupan nyata sehari-hari yang bersifat realistik. Siswa disajikan masalah-masalah kontekstual, yaitu masalah-masalah yang berkaitan dengan situasi realistik. Kata realistik disini dimaksudkan sebagai suatu situasi yang dapat dibayangkan oleh siswa atau menggambarkan situasi dalam dunia nyata (Zulkarnain,2002).

Berdasarkan kajian teori di atas, maka dengan melalui kegiatan penerapan modelmodel pembelajaran melalui kegiatan supervisi akademik dengan pendekatan realistik SMA N 1 Sibolga , kepala sekolah dapat meningkatkan kemampuan guru dalam menerapkan modelmodel pembelajaran melalui kegiatan supervisi akademik dengan pendekatan realistik di SMA N 1 Sibolga

Berdasarkan latar belakang masalah yang diuraikan di atas, maka rumusan masalah dalam penelitian ini adalah sebagai berikut "Apakah penerapan model-model pembelajaran melalui kegiatan supervisi akademik dengan pendekatan realistik dapat meningkatkan mutu pembelajaran siswa." Secara operasional rumusan masalah di atas dapat dijabarkan menjadi beberapa pertanyaan penelitian sebagai berikut :
1. Apakah
penerapan
model-model pembelajaran melalui kegiatan supervisi Akademik dengan pendekatan realistik 
dapat meningkatkan mutu pembelajaran siswa

2. Apa saja kendala-kendala yang dihadapi guru dalam penerapan model-model pembelajaran melalui kegiatan supervisi akademik dengan pendekatan realistik?

3. Bagaimana respon siswa terhadap penerapan model-model pembelajaran melalui kegiatan supervisi akademik dengan pendekatan realistik?

\section{METODE}

Penelitian Tindakan Sekolah ini dilakukan di SMA N 1 Sibolga terhadap sembilan orang guru.

Penelitian ini tergolong penelitian tindakan sekolah, dengan empat langkah pokok yaitu: perencanaan tindakan, pelaksanaan tindakan, pengamatan (observasi), dan refleksi, dengan melibatkan sembilan orang guru SMA N 1 Sibolga. Penelitian dilakukan tahapan secara berkelanjutan selama 3 bulan. Indikator kinerja yang ditetapkan adalah meningkatkan kemampuan guru dalam menerapkan modelmodel pembelajaran melalui kegiatan supervisi akademik dengan pendekatan realistik di SMA N 1 Sibolga. Aspek yang diukur dalam observasi adalah antusiasme guru SMA N 1 Sibolga dalam menerapkan model-model pembelajaran, interaksi siswa dengan guru dalam proses belajar mengajar, interaksi dengan siswa dengan siswa dalam kerja sama kelompok, dan aktivitas siswa dalam diskusi kelompok.

Teknik pengumpulan data dilakukan dengan dokumentasi berupa hasil karya penyusunan KTSP, wawancara dan instrument analisis penilaian.

\section{Perencanaan Tindakan}

a. Pemilihan topik.

b. Melakukan review silabus untuk mendapatkan kejelasan tujuan pembelajaran untuk topik tersebut dan mencari ide-ide dari materi yang ada dalam buku pelajaran. Selanjutnya bekerja dalam kelompok untuk menyusun rencana pembelajaran.

c. Menyusun rencana pelaksanaan pembelajaran.

d. Merencanakanpenerapan pembelajaran

e. Menentukan indikator yang akan dijadikan acuan.

f. Mempersiapkan kelompok mata pelajaran.

g. Mempersiapkan media pembelajaran. h. Membuat format evaluasi.

i. Membuat format observasi.

j. Membuat angket respon guru dan siswa

\section{Pelaksanaan Tindakan}

Menerapkan tindakan sesuai dengan

rencana, dengan langkah-langkah:

a. Setiap guru yang telah menyusun rencana pembelajaran menyajikan atau mempresentasikan rencana pembelajarannya, sementara guru lain memberi masukan, sampai akhirnya diperoleh rencana pembelajaran yang lebih baik.

b. Guru yang ditunjuk menggunakan masukan-masukan tersebut untuk memperbaiki rencana pembelajaran.

c. Guru yang ditunjuk tersebut mempresentasikan rencana pembelajarannya di depan kelas untuk mendapatkan umpan balik.

\section{Pengamatan (observasi)}

a. Observer melakukan pengamatan sesuai rencana dengan menggunakan lembar observasi.

b. Menilai tindakan dengan menggunakan format evaluasi.

c. Pada tahap ini seorang guru melakukan implementasi rencana pembelajaran yang telah disusun, guru lain melakukan observasi dengan menggunakan lembar observasi yang telah dipersiapkan. Selain itu dilakukan pemotretan yang mengclose up kejadian-kejadian khusus selama pelaksanaan pembelajaran.

\section{Refleksi}

Yaitu melakukan renungan, kajian reflektif diri secara inquiri, partisipasi diri (partisipatoris),kolaborasi terhadap latar alamiah dan impiikasi dari suatu tindakan, dengan melakukan analisis terhadap rencana dantindakan yang sudah dilaksanakan dan hasil yang dicapai, dan apa yang belum dapat atau sempat dilakukan.

Hasil dari siklus pertama ini menjadi masukan bagi pelaksanaan siklus kedua yang terdiri dari perulangan keempat langkah yang ada pada siklus pertama. Hal ini terjadi karena dimungkinkan setelah melalui siklus pertama, peneliti menemukan masalah baru atau masalah lama yang belum tuntas, sehingga perlu dipecahkan melalui siklus selanjutnya.

Jika digambarkan, siklus kerja PTS adalah sebagai berikut : 


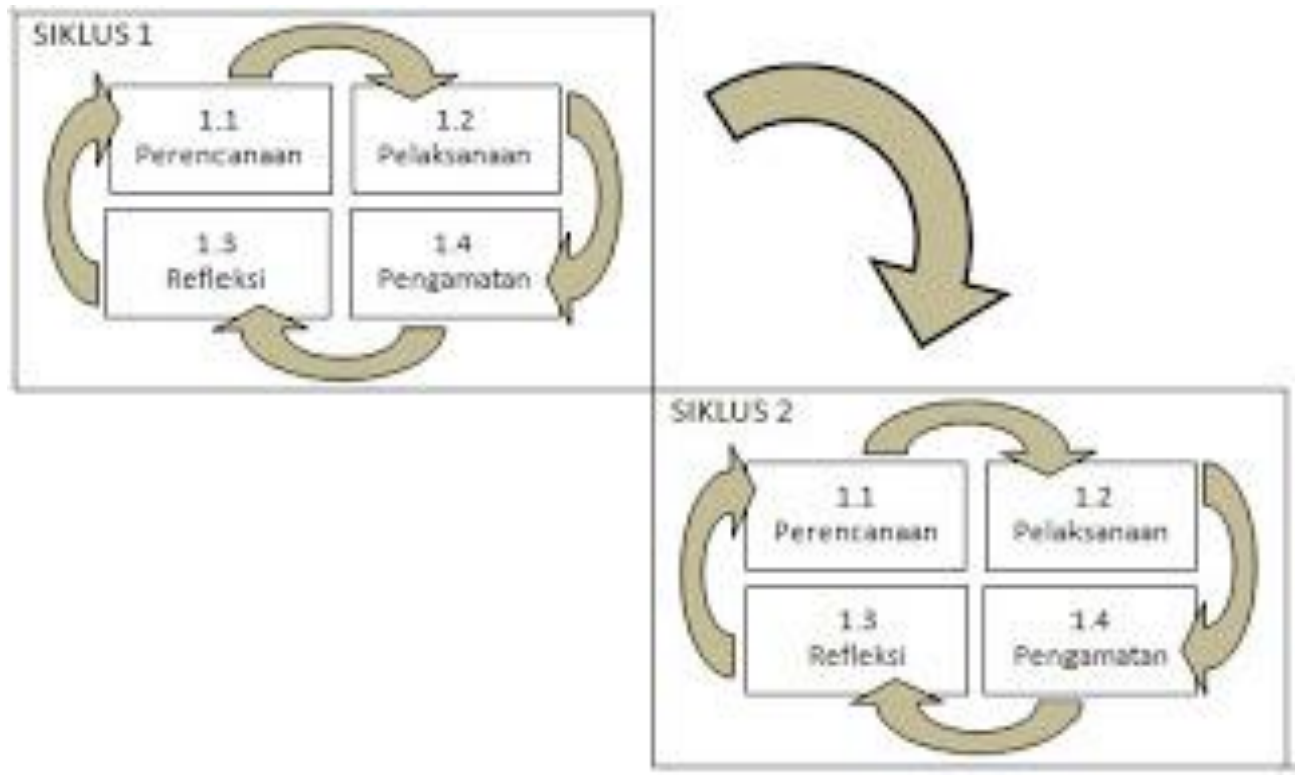

Gambar 1. Siklus kerja Penelitian Tindakan Kelas

\section{Teknis Analisis Data}

Penelitian tindakan sekolah ini berhasil apabila :

1. Peningkatan nilai rata-rata siswa kelas IV, V, VI, Peningkatan nilai rata-rata 6,5.

2. Tingkat aktivitas siswa dalam proses belajar mengajar: Tingkat keaktifan siswa dalam proses belajar mengajar dinilai berhasil apabila masing-masing aktivitas yang menunjang keberhasilan belajar persentasenya di atas $70 \%$.

3. Keterlaksanaan langkah-langkah dalam proses belajar mengajar $\geq 80 \%$.

\section{HASIL DAN PEMBAHASAN \\ HASIL}

Dari hasil wawancara terhadap sembilan orang guru, peneliti memperoleh informasi bahwa semua guru (sembilan orang) belum tahu kerangka penyusunan RPP dengan menerapkan model-model pembelajaran, hanya seorang yang memiliki dokumen standar proses (satu buah), hanya 1 orang guru yang pernah mengikuti pelatihan pengembangan RPP dengan penerapan model-model pembelajaran, umumnya guru mengadopsi dan mengadaptasi RPP yang menerapkan model-model pembelajaran didalamnya, kebanyakan guru tidak tahu dan tidak paham menyusun RPP dengan penerapan model-model pembelajaran secara lengkap, mereka setuju bahwa guru harus menggunakan RPP dengan menerapkan model-model pembelajaran dalam melaksanakan proses pembelajaran yang dapat dijadikan acuan/pedoman dalam proses pembelajaran. Selain itu, kebanyakan guru belum tahu dengan komponen-komponen RPP yang menerapkan model-model pembelajaran secara lengkap.

Berdasarkan hasil observasi peneliti terhadap sembilan RPP yang dibuat guru (khusus pada siklus I), diperoleh informasi/data bahwa masih ada guru yang tidak melengkapi RPP-nya dengan komponen dan subsubkomponen RPP penerapan model pembelajaran tertentu, misalnya komponen indikator dan penilaian hasil belajar (pedoman penskoran dan kunci jawaban). Rumusan kegiatan siswa pada komponen langkahlangkah kegiatan pembelajaran masih kurang tajam, interaktif, inspiratif, menantang, dan sistematis.

Dilihat dari segi kompetensi guru, terjadi peningkatan dalam menyusun Rencana Pelaksanaan Pembelajaran dari siklus ke siklus . Hal itu dapat dilihat pada lampiran Rekapitulasi Hasil Penyusunan RPP penerapan model-model pembelajaran dari Siklus ke Siklus

\section{Siklus I (Pertama)}

Siklus pertama terdiri dari empat tahap yakni: (1) perencanaan, (2) pelaksanaan, (3) pengamatan, dan (4) refleksi seperti berikut ini.

\section{Perencanaan ( Planning )}

a. Membuat lembar wawancara.

b. Membuat format/instrumen penilaian RPP penerapan model-model pembelajaran. 
c. Membuat format rekapitulasi hasil penyusunan RPP penerapan modelmodel pembelajaran siklus I dan II.

d. Membuat format rekapitulasi hasil penyusunan RPP penerapan modelmodel pembelajaran dari siklus ke siklus

\section{Pelaksanaan (Acting)}

Pada saat awal siklus pertama indikator pencapaian hasil dari setiap komponen RPP penerapan model-model pembelajaran belum sesuai/tercapai seperti rencana/keinginan peneliti. Hal itu dibuktikan dengan masih adanya komponen RPP penerapan model-model pembelajaran yang belum dibuat oleh guru. Sebelas komponen RPP penerapan model-model pembelajaran yakni: (1) identitas mata pelajaran, (2) standar kompetensi, (3) kompetensi dasar, 4) indikator pencapaian kompetensi, (5) tujuan pembelajaran, (6) materi ajar, (7) alokasi waktu, metode pembelajaran, (9) langkah-langkah kegiatan pembelajaran, (10) sumber belajar, (11) penilaiaan hasil belajar ( soal, pedoman penskoran, dan kunci jawaban).

\section{Pengamatan}

Hasil pengamatan pada siklus pertama dapat dideskripsikan berikut ini: Pengamatan, terhadap sembilan orang guru. Semuanya menyusun RPP, tapi masih ada guru yang belum melengkapi RPP-nya baik dengan komponen maupun sub-sub komponen RPP penerapan modelmodel pembelajaran tertentu. Satu orang tidak melengkapi RPP penerapan modelmodel pembelajarannya dengan komponen indikator pencapaian kompetensi. Untuk komponen penilaian hasil belajar, dapat dikemukakan sebagai berikut.

- Satu orang tidak melengkapinya dengan teknik dan bentuk instrumen.

- Satu orang tidak melengkapinya dengan teknik, bentuk instumen, soal, pedoman penskoran, dan kunci jawaban.

- Satu orang tidak melengkapinya dengan teknik, pedoman penskoran, dan kunci jawaban.

- Satu orang tidak melengkapinya dengan soal, pedoman penskoran, dan kunci jawaban.

- Satu orang tidak melengkapinya dengan pedoman penskoran dan kunci jawaban.
- Satu orang tidak melengkapinya dengan pedoman penskoran.

Selanjutnya mereka dibimbing dan disarankan untuk melengkapinya.

\section{Siklus II (Kedua)}

Siklus ke juga terdiri dari empat tahap yakni: (1) perencanaan, (2) pelaksanaan, (3) pengamatan, dan (4) refleksi. Hasil pengamatan pada siklus dapat dideskripsikan berikut ini: Pengamatan, terhadap sembilan orang guru. Semuanya menyusun RPP dengan penerapan model-model pembelajaran, tapi masih ada guru yang keliru dalam menentukan kegiatan siswa dalam langkah-langkah kegiatan pembelajaran dan metode pembelajaran, serta tidak memilah/ menguraikan materi pembelajaran dalam subsub materi. Untuk komponen penilaian hasil belajar, dapat dikemukakan sebagai berikut: (1) Satu orang keliru dalam menentukan teknik dan bentuk instrumennya; (2) Satu orang keliru dalam menentukan bentuk instrumen berdasarkan teknik penilaian yang dipilih; (3) Satu orang kurang jelas dalam menentukan pedoman penskoran; (4) Satu orang tidak menuliskan rumus perolehan nilai siswa; dan (5) Selanjutnya mereka dibimbing dan disarankan untuk melengkapinya.

\section{PEMBAHASAN}

Penelitian Tindakan Sekolah dilaksanakan di SMA N 1 Sibolga yang merupakan sekolah binaan peneliti berstatus negeri, terdiri atas sembilan guru, dan dilaksanakan dalam 2 siklus. Kesembilan guru tersebut menunjukkan sikap yang baik dan termotivasi dalam menyusun RPP dengan penerapan model-model pembelajaran dengan lengkap. Hal ini peneliti ketahui dari hasil pengamatan pada saat melakukan wawancara dan bimbingan penyusunan RPP dengan penerapan model-model pembelajaran. Selanjutnya dilihat dari kompetensi guru dalam menyusun RPP dengan penerapan model-model pembelajaran, terjadi peningkatan dari siklus pertama ke siklus kedua.

\section{Komponen Identitas Mata Pelajaran}

Pada siklus pertama semua guru (sembilan orang) mencantumkan identitas mata pelajaran dalam RPP penerapan model-model pembelajarannya (melengkapi RPP penerapan model-model pembelajarannya dengan identitas mata pelajaran). Jika dipersentasekan, 44,4\% atau empat orang guru mendapat skor 3 (baik) 
dan $33,3 \%$ atau tiga orang mendapat skor 4 (sangat baik) dan $22,2 \%$ atau 2 orang guru mendapat skor 2 (cukup baik). Pada siklus kedua kesembilan guru tersebut mencantumkan identitas mata pelajaran dalam RPP penerapan model-model pembelajarannya. Semuanya mendapat skor 4 (sangat baik). Jika dipersentasekan terjadi peningkatan $45 \%$ dari siklus pertama.

\section{Komponen Standar Kompetensi}

Pada siklus pertama semua guru (sembilan orang) mencantumkan standar kompetensi dalam RPP penerapan model-model pembelajarannya (melengkapi RPP penerapan model-model pembelajarannya dengan standar kompetensi). Jika dipersentasekan, $44 \%$. Masing-masing satu orang guru mendapat skor 1, 2, dan 3 (kurang baik, cukup baik, dan baik). 3 orang guru mendapat skor 4 (sangat baik). Pada siklus kedua kesembilan guru tersebut mencantumkan standar kompetensi dalam RPP penerapan model-model pembelajarannya. 3 orang mendapat skor 3 (baik) dan enam orang mendapat skor 4 (sangat baik). Jika dipersentasekan, $78 \%$, terjadi peningkatan $30 \%$ dari siklus pertama.

\section{Komponen Kompetensi Dasar}

Pada siklus pertama semua guru (sembilan orang) mencantumkan kompetensi dasar dalam RPP penerapan model-model pembelajarannya (melengkapi RPP penerapan model-model pembelajarannya dengan kompetensi dasar). Jika dipersentasekan, $66,7 \%$. Masing-masing mendapat skor 1, 2, dan 3 (kurang baik, cukup baik, dan baik). Enam orang guru mendapat skor 4 (sangat baik). Pada siklus ke dua kesembilan guru tersebut mencantumkan kompetensi dasar dalam RPP penerapan model-model pembelajarannya. Satu orang mendapat skor 3 (baik) dan enam orang mendapat skor 4 (sangat baik). Jika dipersentasekan, $78 \%$, terjadi peningkatan 11,3 $\%$ dari siklus pertama.

\section{Komponen Indikator Pencapaian Kompetensi}

Pada siklus pertama tujuh orang guru mencantumkan indikator pencapaian kompetensi dalam RPP penerapan model-model pembelajarannya (melengkapi RPP penerapan model-model pembelajarannya dengan indikator pencapaian kompetensi). Sedangkan satu orang tidak mencantumkan /melengkapinya. Jika dipersentasekan, 56\%. orang guru masing-masing mendapat skor 1 dan 2 (kurang baik dan cukup baik). Empat orang guru mendapat skor 3 (baik), satu orang guru mendapat skor 4 (sangat baik). Pada siklus kedua ke kesembilan guru tersebut mencantumkan indikator pencapaian kompetensi dalam RPP penerapan model-model pembelajarannya. Satu orang mendapat skor 2 (cukup baik). Enam orang mendapat skor 3 (baik) dan satu orang mendapat skor 4 (sangat baik). Jika dipersentasekan, 78\%, terjadi peningkatan $22 \%$ dari siklus pertama.

\section{Komponen Tujuan Pembelajaran}

Pada siklus pertama semua guru (sembilan orang) mencantumkan tujuan pembelajaran dalam RPP penerapan modelmodel pembelajarannya (melengkapi RPP penerapan model-model pembelajarannya dengan tujuan pembelajaran). Jika dipersentasekan, $63 \%$. Satu orang guru mendapat skor 1 (kurang baik), orang mendapat skor 2 (cukup baik), dan lima orang mendapat skor 3 (baik), satu orang mendapat skor 4 (sangat baik). Pada siklus kedua kesembilan guru tersebut mencantumkan tujuan pembelajaran dalam RPP penerapan modelmodel pembelajarannya. Lima orang mendapat skor 3 (baik) dan tiga orang mendapat skor 4 (sangat baik). Jika dipersentasekan, 89\%, terjadi peningkatan $26 \%$ dari siklus pertama.

\section{Komponen Materi Ajar}

Pada siklus pertama semua guru (sembilan orang) mencantumkan materi ajar dalam RPP penerapan model-model pembelajarannya (melengkapi RPP penerapan model-model pembelajarannya dengan materi ajar). Jika dipersentasekan, 66\%. Satu orang guru masing-masing mendapat skor 1 dan 4 (kurang baik dan sangat baik), orang mendapat skor 2 (cukup baik), dan empat orang mendapat skor 3 (baik), 2 orang mendapat skor 4 (sangat baik). Pada siklus ke kesembilan guru tersebut mencantumkan materi ajar dalam RPP penerapan model-model pembelajarannya. Enam orang mendapat skor 3 (baik) dan dua orang mendapat skor 4 (sangat baik). Jika dipersentasekan, $89 \%$, terjadi peningkatan $23 \%$ dari siklus pertama.

\section{Komponen Alokasi Waktu}

Pada siklus pertama semua guru (sembilan orang) mencantumkan alokasi waktu 
dalam RPP penerapan model-model pembelajarannya (melengkapi RPP penerapan model-model pembelajaran penerapan modelmodel pembelajarannya dengan alokasi waktu). 7 orang guru mendapat skor 3 (baik). Jika dipersentasekan, 78\%. Pada siklus kedua kesembilan guru tersebut mencantumkan alokasi waktu dalam RPP penerapan modelmodel pembelajarannya. Tiga orang mendapat skor 3 (baik) dan lima orang mendapat skor 4 (sangat baik). Jika dipersentasekan, 89\%, terjadi peningkatan $11 \%$ dari siklus pertama.

\section{Komponen Metode Pembelajaran}

Pada siklus pertama semua guru (sembilan orang) mencantumkan metode pembelajaran dalam RPP penerapan modelmodel pembelajarannya (melengkapi RPP penerapan model-model pembelajarannya dengan metode pembelajaran). Jika dipersentasekan, $66 \%$. Satu orang guru mendapat skor 2 (cukup baik), lima orang mendapat skor 3 (baik), dan satu orang mendapat skor 4 (sangat baik). Pada siklus kedua kesembilan guru tersebut mencantumkan metode pembelajaran dalam RPP penerapan model-model pembelajarannya. tujuh orang mendapat skor 3 (baik), dan dua orang mendapat skor 4 (sangat baik). Jika dipersentasekan, 99\%, terjadi peningkatan 33\% dari siklus pertama.

\section{Komponen Langkah-Langkah Kegiatan Pembelajaran}

Pada siklus pertama semua guru (sembilan orang) mencantumkan langkahlangkah kegiatan pembelajaran dalam RPP penerapan model-model pembelajarannya (melengkapi RPP penerapan model-model pembelajarannya dengan langkah-langkah kegiatan pembelajaran). Jika dipersentasekan, $53 \%$. Tujuh orang guru mendapat skor 2 (cukup baik), sedangkan satu orang mendapat skor 3 (baik). Pada siklus ke kesembilan guru tersebut mencantumkan langkah-langkah kegiatan pembelajaran dalam RPP penerapan modelmodel pembelajarannya. tujuh orang mendapat skor 3 (baik), satu orang mendapat skor 4 (sangat baik). Jika dipersentasekan, 89\%, terjadi peningkatan $36 \%$ dari siklus pertama.

\section{Komponen Sumber Belajar}

Pada siklus pertama semua guru (sembilan orang) mencantumkan sumber belajar dalam RPP penerapan model-model pembelajarannya (melengkapi RPP penerapan model-model pembelajarannya dengan sumber belajar). Jika dipersentasekan, 66\%. Tiga orang guru mendapat skor 2 (cukup baik), sedangkan lima orang mendapat skor 3 (baik), satu orang mendapat skor 4 (sangat baik). Pada siklus kedua kesembilan guru tersebut mencantumkan sumber belajar dalam RPP penerapan modelmodel pembelajarannya. Satu orang mendapat skor 2 (cukup baik) dan enam orang mendapat skor 3 (baik), dua orang guru mendapat skor 4 (sangat baik). Jika dipersentasekan, 89\%, terjadi peningkatan $23 \%$ dari siklus pertama.

\section{Penilaian Hasil Belajar}

Pada siklus pertama semua guru (sembilan orang) mencantumkan penilaian hasil belajar dalam RPP penerapan model-model pembelajarannya meskipun sub-sub komponennya (teknik, bentuk instrumen, soal), pedoman penskoran, dan kunci jawabannya kurang lengkap. Jika dipersentasekan, $66 \%$. orang guru masing-masing mendapat skor 1 dan 2 (kurang baik dan baik), satu orang mendapat skor 3 (cukup baik), lima orang guru mendapat skor 3 (baik) dan satu orang mendapat skor 4 (sangat baik). Pada siklus kedua kesembilan guru tersebut mencantumkan penilaian hasil belajar dalam RPP penerapan model-model pembelajarannya meskipun ada guru yang masih keliru dalam menentukan teknik dan bentuk penilaiannya. Tujuh orang mendapat skor 3 (baik) dan satu orang mendapat skor 4 (sangat baik). Jika dipersentasekan, $89 \%$, terjadi peningkatan $23 \%$ dari siklus pertama.

Berdasarkan pembahasan di atas terjadi peningkatan kompetensi guru dalam menyusun RPP penerapan model-model pembelajaran. Pada siklus pertama rata-rata Komponen Identitas Mata Pelajaran 44,4\%, pada siklus kedua $100 \%$, terjadi peningkatan 55,6\% dari siklus pertama. Pada siklus pertama rata-rata Komponen Standar Kompetensi 44\%, pada siklus kedua $78 \%$, terjadi peningkatan $30 \%$ dari siklus pertama.. Pada siklus pertama rata-rata Komponen Indikator Pencapaian Kompetensi $56 \%$, pada siklus kedua $78 \%$, terjadi peningkatan $11,7 \%$ dari siklus pertama. Pada siklus pertama rata-rata Komponen Tujuan Pembelajaran 63\%, pada siklus kedua $78 \%$, terjadi peningkatan $22 \%$ dari siklus pertama. Pada siklus pertama rata -rata Komponen Tujuan Pembelajaran 63\%, pada siklus kedua $89 \%$, terjadi peningkatan $26 \%$ dari siklus 
pertama. Pada siklus pertama rata-rata Komponen Materi Ajar 66\%, pada siklus kedua $89 \%$, terjadi peningkatan $23 \%$ dari siklus pertama. Pada siklus pertama rata-rata Komponen Alokasi Waktu 78\%, pada siklus kedua $89 \%$, terjadi peningkatan $11 \%$ dari siklus pertama. Pada siklus pertama rata-rata Komponen Metode Pembelajaran 66\%, pada siklus kedua $99 \%$, terjadi peningkatan $33 \%$ dari siklus pertama. Pada siklus pertama rata-rata Komponen Langkah-Langkah Kegiatan Pembelajaran 53\%, pada siklus kedua $89 \%$, terjadi peningkatan $36 \%$ dari siklus pertama. Pada siklus pertama Komponen Sumber Belajar $66 \%$, pada siklus kedua $89 \%$, terjadi peningkatan $23 \%$ dari siklus pertama. Pada siklus pertama rata-rata komponen Penilaian Hasil Belajar 66\%, pada siklus kedua 89\%, terjadi peningkatan $23 \%$ dari siklus pertama.

\section{PENUTUP}

Berdasarkan hasil Penelitian Tindakan Sekolah (PTS) dapat disimpulkan sebagai berikut:

(1) Bimbingan dan pengawasan yeng berkesinambungan dapat meningkat- kan motivasi guru dalam menyusun RPP dengan lengkap. Keseriusan dan pemahaman guru semakin bertambah dalam menyusun RPP seiring dengan bimbingan dan pengawasan yang diterapkan kepada guru-guru.Informasi ini diperoleh dari hasil wawancara dan pengamatan selama bimbingan pengembangan/penyusunan RPP kepada para guru.

(2) Bimbingan berkesinambungan dapat meningkatkan kompetensi guru dalam menyusun RPP. Hal itu dapat dibuktikan dari hasil observasi /pengamatan yang memperlihatkan bahwa terjadi peningkatan kompetensi guru dalam menyusun RPP dari siklus ke siklus . Pada siklus pertama nilai rata-rata komponen RPP $60,5 \%$ dan pada siklus kedua $87,9 \%$. Jadi, terjadi peningkatan $27,4 \%$ dari siklus pertama.

(3) Supervisi akademik membuka cakrawala berpikir guru, untuk memandang dirinya, menemukan kesalahan dan solusi atas kompetensi diri guru itu sendiri.
Arikunto, Suharsimi. (2002). Prosedur Penelitian, Suatau Pendekatan Praktek, Jakarta: Rineka Cipta.

Darma Surya, (2009). Bahan Belajar Mandiri Dimensi Kompetensi Suvervisi. Jakarta: Direktorat jendral peningkatan Mutu pendidikan Nasional

Erman Suherman, (2009). Model-model Pembelajaran http ://researchengines.com/1207trimo1.html Penelitian Tindakan Sekolah

Fattah, Nanang. (2003). Landasan Manajemen Pendidikan. Bandung: Remaja Rosda Karya.

S, Syaodih Nana, (2006). Pengendalian Mutu Pendidikan Sekolah

Menengah(konsep,prinsif,dan instrumen). Bandung : Aditama.

Sagala, Syaiful. (2010). Supervisi Pembelajaran Dalam Profesi Pendidikan, Bandung Alfabeta (2011). Konsep dan Makna Pembelajaran. Bandung: Alfabeta

Undang-undang Republik Indonesia Nomor 20 Tahun 2003 tentang Sistem Pendidikan Nasional.

Peraturan Pemerintah Nomor 19 tahun 2005 tentang Standar Nasional Pendidikan.

Peraturan Pemerintah Nomor 22 tahun 2006 tentang Standar Isi untuk Satuan Pendidikan Dasar dan Menengah.

Piet, A. Sahertian. Frans Mataheru, (1981). Prinsip Teknik Supervisi Pendidikan. Surabaya :Usaha Nasional.

\section{DAFTAR PUSTAKA}

